\title{
Knowledge, Attitude, and Practice Regarding COVID-19 among Residents of Pesantren
}

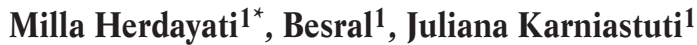

${ }^{1}$ Department of Population and Biostatistics, Faculty of Public Health, Universitas Indonesia, Depok, Indonesia

\begin{abstract}
Islamic boarding schools (pesantren) run the risk of COVID-19 transmission. The pesantren learning system is generally carried out collectively, with an allday-long interaction between teachers and students. This paper presented a lesson on controlling COVID-19 outbreak in pesantren through Community Service Activities (CSA). The CSA was designed to empower the pesantren to prevent and control COVID-19 to become a safe place protected from COVID-19 spread. This was a relevant case study in a traditional Islamic boarding school (salafiah) in Lebak District, Banten. The study population (a total of 97 participants) consisted of the pesantren leader, the teachers ("Ustaz/Ustazah"), and the students, ushered by the community service partners, namely the Sub-district Public Health Center and COVID-19 Task Force. This study showed that controlling COVID-19 in pesantren requires the leaders' commitment to establishing an internal COVID-19 Task Force and partnerships with community stakeholders. Health literacy needs to be improved, especially by implementing health protocols and information on clean and healthy behavior. There are obstacles in handling COVID-19, especially related to social distancing, infrastruc-ture, and funding. This study recommends the empowerment of pesantren residents related to health literacy. It is necessary to make people realize that COVID-19 is everyone's responsibility. The Government should pay serious attention to pesantren as boarding educational institutions with a high level of in-teraction and prevent them from becoming clusters of COVID-19 spread.
\end{abstract}

Keywords: COVID-19, empowerment, Islamic boarding school, pesantren

\section{Introduction}

Islamic boarding schools ("Pesantren" in Indonesia) constitute one of the educational settings that are a potential source of COVID-19 transmission. Many religious practices and learning patterns pertaining to the pesantren system make them a risk of becoming clusters for COVID-19 spread. The practice of shaking hands between "santri" and "Kiai/Ustaz/Ustazah" (students and pesantren leader/teachers, respectively) and teaching procedures carried out collectively, such as congregational prayer, the study of Qur'an, and classical literature, are standard everyday procedures in pesantren. Furthermore, the busy activities of the "santri" and their interaction on a day-long basis make the boarding school environment vulnerable to the spread of COVID-19. ${ }^{1-3}$

Controlling COVID-19 transmission in pesantren is crucial. According to the DataBase of Islamic Boarding Schools of the Ministry of Religion in 2021, the number of pesantren is 27,722 with a total of $4,175,555$ students. ${ }^{4}$ A considerable number of the institutions are

Correspondence*: Milla Herdayati, Department of Population and Biostatistics, Faculty of Public Health, Universitas Indonesia, Building A, 2nd Floor, Kampus Baru, UI Depok 16424, Indonesia, E-mail: millaherdayati@gmail.com, Phone: +62-21-7863473, Fax: +62-21-7871636 located in the red zone districts and cities in Indonesia. ${ }^{4}$ According to data from LaporCOVID-19, there were 8,291 positive cases of COVID-19 in pesantren. ${ }^{5}$ These data do not represent the actual condition because not all pesantren have reported the cases of COVID-19. 5

In an effort to confront the COVID-19 pandemic, the Indonesian Government issued Presidential Decree No. 11 of 2020 regarding "Stipulation of Public Health Emergencies for Corona Virus Disease 2019 (COVID-19)" that requires countermeasures, ${ }^{6}$ one of which was at home or at-distance online education. This regulation applies to all educational institutions. Pesantren as education provider institutions responded to this policy differently. Some pesantren decided to return all or some of the students home, while others continued to study in pesantren. Ministry of Religious Affairs (MORA) has surveyed 1,262 pesantren. About 9.12\% did not encour-age the students to return home because the pesantren environment was considered safer

Received : May 8, 2021

Accepted : July 13, 2021

Published: July 31, 2021 


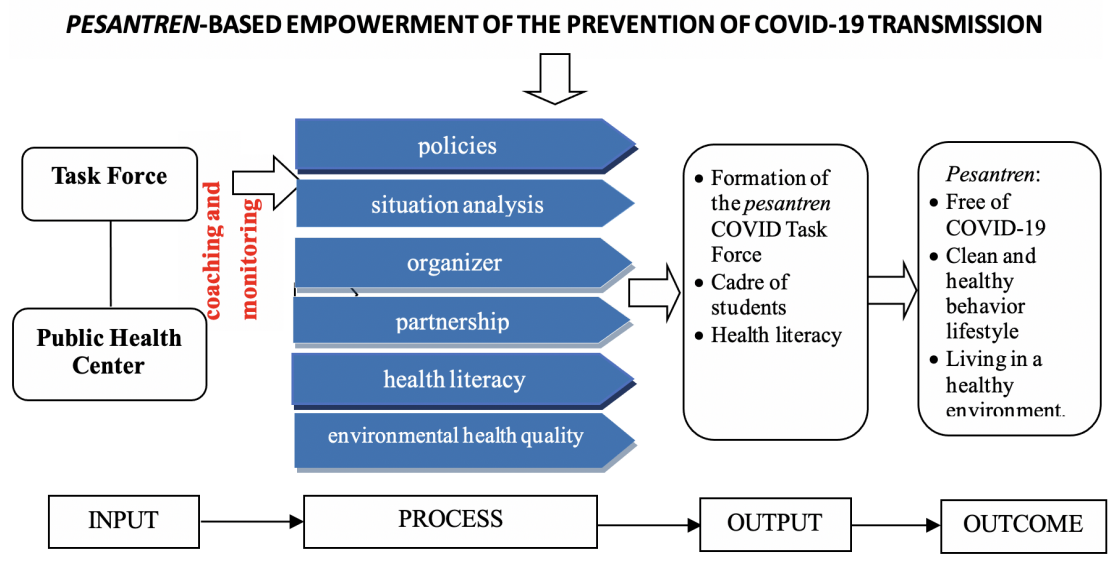

Figure 1. The Community Empowerment Stages 9

(77.6\%) and studying there was better (14.7\%); to a lesser degree, it was the wish of the parents $(7.7 \%){ }^{7}$

Apparently, online education was not an option for pesantren. When the Indonesian Government issued a policy called the New Normal, i.e., several adjustment policies during the pandemic, the majority of the $p e$ santren $(85 \%)$ asked their students to return to presential classes. While the remaining $15 \%$ decided to continue the online modality, ${ }^{7}$ even though they face various obstacles when implementing at-distance learning. Generally, pesantren in Indonesia are located in rural areas, especially the traditional salafiah pesantren, where internet access is limited, and many students come from various regions. 2,8 Furthermore, most learning processes in pesantren are carried out in groups, especially worship practice. This makes the online processes difficult to implement. Therefore, many pesantren have remained or started new presential learning, even though the spread of COVID-19 in Indonesia is not under control. ${ }^{8}$

The Indonesian Government has issued the Decree of Minister of Health Number HK.01.07/MENKES/2322/2020 regarding "Guidelines for Empowering Islamic Boarding School Communities in the Prevention and Control of Coronavirus Disease 2019 (COVID-19) in Islamic Boarding Schools". 9 The decision, which should be followed without exception by the whole country, stipulates the health protocols that pesantren should apply that run presential activities. Based on this background, the researchers felt the need to investigate the efforts of pesantren in preventing and controlling COVID-19 so that they can be places of learning protected against COVID-19 transmission. This paper aimed to describe the stages of the pesantren-based empowerment process for controlling COVID-19, its challenges, and obstacles. This study was expected to be a source of information for pesantren in Indonesia, especially traditional pesantren preparing them for the return to presential courses.

\section{Method}

This is a case study on the empowerment of Islamic boarding schools (pesantren) in preventing and controlling COVID-19. The pesantren chosen was a traditional Islamic boarding school (salafiah) in Lebak District, Banten. Lebak District is a region with a large number of pesantren, where almost every village has at least one. Therefore, Lebak District is one of among COVID-19 spread high-risk regions. On March 9, 2021, the number of confirmed positive cases for COVID-19 was 2,767 people in total, with 56 deceased people, 1,970 recovered cases, and 740 people in isolation. 10

The Community Services Activities (CSA) were carried out in six months, from July to December 2020. The study group consisted of the pesantren leaders, the teachers ("Ustaz/Ustazah"), and the students ("santri/santri$a t$ ”), a total of 97 people (30 women and 67 men). Meanwhile, community service partners consisted of the Sub-district's Public Health Center and the COVID-19 Task Force. The empowerment of pesantren in controlling COVID-19 is organized in the community service stages described in Figure 1. These stages were adapted from the COVID-19 Control Guidelines in pesantren issued by the Ministry of Health of the Republic of Indonesia. ${ }^{9}$

The empowerment strategy was carried out through the following activities: 1) issuing policies for the prevention and control of COVID-19 in pesantren; 2) analyzing the situation inside the pesantren; 3) organizing the prevention and control of COVID-19; 4) building partnerships to optimize activities; 5 ) increasing health literacy; 6) improving the quality of pesantren's environmental health, and 7) guidance and monitoring. ${ }^{9}$ The situation analysis was applied to collect data on teachers' knowledge, attitudes, and behavior through online surveys (Google Forms) via cellphones. In contrast, student data were collected through the computers of the pesantren since they are not allowed to carry cellphones while living in the pesantren. 


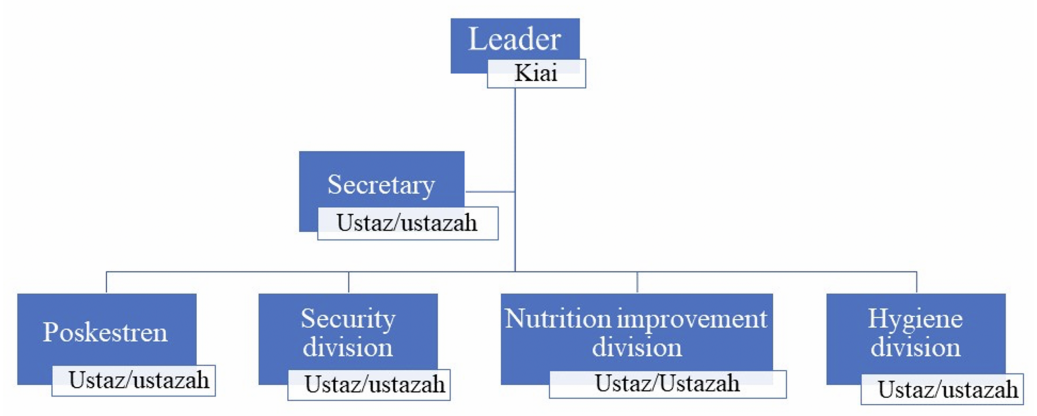

Figure 2. The Pesantren COVID-19 Task Force

Table 1. Knowledge of Pesantren Residents about COVID-19 (\%)*

\begin{tabular}{|c|c|c|c|}
\hline Knowledge Statement & $\begin{array}{c}\text { Teachers } \\
(n=11)\end{array}$ & $\begin{array}{c}\text { Students } \\
(\mathrm{n}=86)\end{array}$ & $\begin{array}{l}\text { Total } \\
(\mathrm{n}=97)\end{array}$ \\
\hline Everyone infected with the coronavirus will show symptoms & 90.9 & 76.7 & 78,4 \\
\hline The coronavirus is transmitted through droplets/fluids that come out when someone sneezes/coughs & 100.0 & 100.0 & 100.0 \\
\hline The coronavirus is transmitted through physical contact with an infected person (touching/shaking hands) & 100.0 & 100.0 & 100.0 \\
\hline The coronavirus is transmitted through the air & 100.0 & 100.0 & 100.0 \\
\hline $\begin{array}{l}\text { You can be infected with COVID-19 if you touch your mouth/nose/eyes with your hands previously } \\
\text { exposed to the coronavirus }\end{array}$ & 90.9 & 100.0 & 99.0 \\
\hline Washing hands with soap and running water can prevent transmission of the coronavirus & 100.0 & 100.0 & 100.0 \\
\hline People infected with the coronavirus without symptoms can still transmit the virus to other people & 100.0 & 97.7 & 97.9 \\
\hline The use of masks is an effective measure to prevent transmission of the coronavirus & 100.0 & 100.0 & 100.0 \\
\hline Staying at home is an effective measure to prevent the spread of the coronavirus & 100.0 & 100.0 & 100.0 \\
\hline COVID-19 infection can be prevented with spices/herbs ( "empon-empon" in Indonesia) & 100.0 & 100.0 & 100.0 \\
\hline Avoiding shaking hands is effective in preventing transmission of the coronavirus & 100.0 & 100.0 & 100.0 \\
\hline Maintaining a physical distance of at least one meter can prevent transmission of the coronavirus & 100.0 & 100.0 & 100.0 \\
\hline
\end{tabular}

*Percentage of the respondents that answered correctly

\section{Results}

Several stages of activities were applied to the COVID-19 empowerment, prevention, and control strategies in Figure 1. Next, each one is laid out.

\section{Policy Development and Organizing the Prevention and Control of COVID-19 in Pesantren}

The first step was to encourage the pesantren leader to issue policies related to the prevention and control of COVID-19. This policy was carried out by forming a Pesantren COVID-19 Task Force where the leader of $p e$ santren acts as the Chairman of Task Force. The structure of the Task Force can be seen in Figure 2. The Task Force has four divisions, namely: 1) Poskestren ( $p e$ santren Health Post), 2) nutrition improvement, 3) hygiene, and 4) security. The four sectors have their respective duties and functions. An "Ustaz/Ustazah" chairs each field," and each sector is assisted by the "santri/ santriat" of the pesantren.

\section{Pesantren Situation Analysis Assistance}

Next, the pesantren COVID-19 Task Force applied a situation analysis that aimed to obtain primary data on the current situation and condition of the pesantren. The data collection was carried out by "santri," containing: 1) the profile of the pesantren (the building area, the number of "santri/santriat," the number of "Ustaz/Ustazah," the number of employees, the number and condition of facilities such as study rooms, dormitories, worship area, living room, kitchen, toilets, bathrooms, number of basins with soap and running water); 2) the learning system; 3) analysis of the potential resources, opportunities, and constraints; and 4) knowledge, attitudes, and behavior of the pesantren residents related to the prevention of COVID-19. Data collection was carried out regularly using instruments that havebeen prepared specifically for the COVID-19 situation. 
Data concerning the knowledge, attitudes, and behavior of the pesantren residents related to COVID-19 were collected. In Table 1, it is illustrated that the relevant knowledge was generally of good level. However, some areas were still to be improved, especially concerning the statement that "not all infected people will show symptoms but can transmit the COVID-19 virus".

Table 2 shows a tendency for a positive attitude of the students toward COVID-19. However, some attitudes need to be improved, i.e., wearing masks, maintaining distance, and avoiding physical contact. Some students did not agree to keep their distance in congregation prayer at mosques, prayer rooms, or other public places.
Regarding the use of masks, some students did not agree to wear masks when meeting with other people (e.g., relatives, friends, neighbors, other students) and practicing congregation prayer. The attitude of students toward physical contact should also be improved. Some students did not agree to avoid shaking hands or having physical contact when meeting with the "Kiai" or other social circle members. Besides, a stigma of disagreement over the bodies of those who died of COVID-19 should be accepted like other Muslims or not must be discussed and rectified.

The attitude of the pesantren residents toward COVID-19 appears to be in line with their behavior, as seen in Table 3. Over the last two weeks, many of the

Table 2. Attitudes of Pesantren Residents towards COVID-19 (\%)*

\begin{tabular}{lccc}
\hline Attitudes & $\begin{array}{c}\text { Teachers } \\
(\mathbf{n = 1 1})\end{array}$ & $\begin{array}{c}\text { Students } \\
(\mathbf{n}=\mathbf{8 6})\end{array}$ & $\begin{array}{c}\text { Total } \\
(\mathbf{n}=\mathbf{9 7})\end{array}$ \\
\hline Wearing masks only when sick & 9.1 & 2.3 & 3.1 \\
Maintaining a distance during congregational prayers in mosques/prayer rooms or other public places & 90.9 & 94.2 & 93.8 \\
Wearing a mask during congregational prayers & 54.5 & 64.0 & 62.9 \\
Wearing a mask when attending recitation/religious study/prayer & 100.0 & 100.0 & 100.0 \\
Wearing a mask when meeting relatives/friends/neighbors/other students/etc. & 100.0 & 100.0 & 100.0 \\
Maintaining a distance when attending recitation/religious study/prayer & 100.0 & 97.7 & 97.9 \\
Avoiding shaking hands/physical contact when meeting with relatives/friends/other students etc. & 100.0 & 100.0 & 100.0 \\
Avoiding damage takes precedence over taking benefits & 100.0 & 97.7 & 97.9 \\
Those infected with COVID-19 need independent isolation for 14 days & 100.0 & 95.3 & 95.9 \\
Those who come in direct contact with sufferers must isolate independently for 14 days & 100.0 & 98.8 & 99.0 \\
Families infected with COVID-19 need assistance in providing food during isolation & 100.0 & 100.0 & 100.0 \\
\hline
\end{tabular}

*Percentage of the respondents that answered "agree"

Table 3. The Behavior of Pesantren Residents in the Last Two Weeks (\%)*

\begin{tabular}{|c|c|c|c|}
\hline Behaviors & $\begin{array}{c}\text { Teachers } \\
(n=11)\end{array}$ & $\begin{array}{c}\text { Students } \\
(\mathrm{n}=86)\end{array}$ & $\begin{array}{c}\text { Total } \\
(\mathrm{n}=97)\end{array}$ \\
\hline Leaving the house only for certain purposes & 18.2 & 1.2 & 3.1 \\
\hline Wash your hands with soap and running water after traveling & 81.8 & 96.5 & 94.8 \\
\hline Carry a hand sanitizer outside the house & 63.6 & 95.3 & 91.8 \\
\hline Wear masks when leaving the house/meeting with other people & 90.9 & 100.0 & 99.0 \\
\hline Shake hands when meeting other people & 27.3 & 54.7 & 51.5 \\
\hline Wear masks during congregational prayer at the mosque/prayer room & 63.6 & 70.9 & 70.1 \\
\hline Keep a distance during congregational prayer at the mosque/prayer room & 100.0 & 91.9 & 92.8 \\
\hline Wear masks while attending recitation at the mosque/prayer room & 90.9 & 97.7 & 96.9 \\
\hline Keep a distance while attending recitation at the mosque/prayer room & 100.0 & 96.5 & 96.9 \\
\hline
\end{tabular}

*Percentage of the respondents that answered "often" 
students stated that they often shook hands $(52 \%)$, did not wear masks $(30 \%)$, and did not keep their distance during congregational worship (7\%). This suggested that students' adherence to health protocols should be increased through routine education.

\section{Building Partnerships with the Regional Public Health Center and the Local COVID-19 Task Force}

Partnerships were built to collaborate in the prevention and control of COVID-19 to optimize community service activities. The collaboration partners consisted of the regional Public Health Center and COVID-19 Task Force. They acted as supervisors and monitor for COVID-19 control activities in pesantren. All the parties coordinated if a positive case of COVID-19 was present in the pesantren, the 3T procedure (testing, tracing, and treatment) or independent isolation could follow up.

\section{Improving Health Literacy for Pesantren Residents}

Based on the description of knowledge, attitudes, and behavior, increasing health literacy about the prevention and control of COVID-19 must be promoted among the pesantren residents. Literacy improvement is carried out through counseling and information dissemination through leaflets, flyers, posters, and banners. Counseling was carried out in the pesantren with local partners and pesantren leaders as resources' person. Educational material was provided from a health perspective and a religious (Islamic) perspective, aiming at reducing misperceptions regarding the coronavirus, the methods of transmission and prevention, and correcting misunderstandings about the COVID-19 outbreak. Apart from counseling, literacy was carried out by providing IEC COVID-19 material in the form of leaflets and standing banners containing information on health protocols. The material was adapted from the same materials issued by the Ministry of Health of the Republic of Indonesia in 2020.

\section{Discussion}

Studies related to handling COVID-19 in boarding schools have not been widely conducted. The findings of this study were in line with previous studies showing that the main challenge is social distancing and infrastructure-related issues. ${ }^{11,12}$ The boarding schools must consider the capacity of bedrooms, bathrooms, social activities areas, and alternatives for the supplies (e.g., meals). The social distancing recommended by the WHO protocol and the available spaces should take into account the increasing transmissibility of the coronavirus. ${ }^{13} \mathrm{WHO}$ recommended the distance of two meters between individuals, or one meter where extra precautions are in place (such as covering the face or applying extra indoor ventilation). ${ }^{13}$ These protocols can be problematic for boarding schools.

This CSA received good responses from the pesantren residents as well as the Sub-district Public Health Center and the Sub-district COVID-19 Task Force. Indirectly, CSA supported their primary duties and functions to strengthen the control of COVID-19 in educational institutions in their region, including pesantren. The commitment of the pesantren leaders was an initial and important step in controlling COVID-19 inside the boarding institution. They encouraged the active involvement of pesantren administrators, students, and other residents to prevent and control COVID-19. Leaders must incite and monitor the pesantren residents' adaptation to the "new normal" era's new habits. The monitoring was done by applying health protocols by ensuring the availability of supporting infrastructures such as basins with soap and running water, suitable dormitories, and independent isolation rooms according to the health protocol. The biggest challenge in pesantren was physical distancing. The learning schemes of pesantren are generally carried out collectively/in a congregation. The interaction between students is almost 24 hours a day, and the santri dormitory inhabited by several santri in the same room needs to be adjusted to the COVID-19 health protocol. ${ }^{2}$

Partnerships and collaboration between pesantren, the Sub-district COVID-19 Task Force, and Public Health Center must be built and fostered. This supports the 3T efforts to be carried out optimally. The involvement of local partners was an essential factor since the adoption of health information by the community was determined by the trust in the local community. ${ }^{14}$ Through partnerships and collaboration, the chain of transmission of COVID-19 can be broken, and positive cases can be handled quickly. Increasing health literacy among the pesantren residents needs to be carried out continuously with guidance and monitoring from the two partners. This effort aimed to change wrong assumptions regarding the prevention of COVID-19, especially the physical distancing, the advice not to shake hands, and maintain a distance during worship.

Increasing health literacy needs to continue on a regular basis to change wrong opinions of the community, which often contradict government policies, such as the case of the fatwa of the Indonesian Council of Ulama No. 14 of 2020 concerning the implementation of worship in the COVID-19 pandemic. ${ }^{15}$ Several common ritual practices, such as prayer congregation, are recommended to be replaced with praying at home. This recommendation is related to preventing the gathering of people in mosques. It prohibits people from praying in mosques, not from neglecting their religious obligations. It is not forbidden to pray in congregation at the mosque, nor is it forbidden to gather in congregation recitation, but it acts toward the personal and community protection from the dangers of COVID-19.16

Education to prevent social stigma against residents of pesantren, "santri," and surrounding communities 
positive for COVID-19 needs to be applied, including managing the bodies of COVID-19 patients. The spirit of cooperation in overcoming the transmission of COVID19 in the community also needs to be built in the literacy of pesantren. Controlling COVID-19 requires the collaboration of all parties. Many lessons were learned from the empowerment process at the Al Marjan Lebak Islamic Boarding School in Banten concerning challenges, obstacles, and opportunities.

Implementing health protocols in the pesantren environment must be strict. Health protocols include wearing masks, maintaining a minimum physical distance of two meters from other people, avoiding the crowds, and washing one's hands frequently with soap and running water to ensure compliance with the health protocols. It was necessary to impose sanctions on the pesantren residents who violate them. No less important was imple-menting Clean and Healthy Behavior such as personal hygiene and cleanliness of the pesantren environment. Some examples of behaviors that needed to be encouraged to increase students' immunity were physical exercise, consumption of nutritious food, keeping the living environment clean. The COVID-19 Task Force, along with cadres, must monitor the compliance of students to health protocols.

Pesantren learning settings that adapt to the "new normal" era must be implemented. The application of physical distancing by keeping the students' seats at a distance impacted the classrooms' capacity. The classrooms now have only half or one-third of the original capacity. The entrance pattern of the students in the classroom could be organized in shifts and the practice of worship. ${ }^{17} \mathrm{~A}$ one-gate system policy that limited the mobility of people in and out of the pesantren environment made the interaction between the students and the outside community easier to monitor. This rule should apply to all the pesantren residents, including "Ustaz/Ustazah" (teachers) and other staff.

Furthermore, the number of visits needs to be limited. It aimed to reduce the frequency of the meetings between the residents and outside community running the risk of transmitting the coronavirus. The visiting schedule for the "santri" guardians also needs to be limited. When a student's guardian meets their child, maintaining a safe distance and prohibitions on physical contact must be enforced. In addition, the guardian delivery of packages for "santri" must also be limited in frequency (for example, once a month), and the reception should be regulated through a sterilization process. All students must test for COVID-19 before entering the pesantren area through rapid tests or swab tests. If the tests were positive, the "santri" must undergo independent isolation. This is applied to limit the risk of COVID-19 transmission within the school's facilities.
It is necessary to routinely update records related to the risk factors for COVID-19, including the physical condition complaints by all the pesantren residents. This can serve as an initial detection of COVID-19 cases, making it efficient to handle and trace possible transmission quickly. The pesantren work together with local health centers and the COVID-19 Task Force so that case handling and transmission control could be carried out. This routine data collection was carried out by the pesantren COVID-19 Task Force, specifically the pesantren Health Post (Poskestren). ${ }^{18}$

Controlling COVID-19 in pesantren while they adapt to the "new normal" era certainly has implications for the provision of modified learning infrastructure, such as classroom and dormitory capacity changes, toilets, and basins soap. ${ }^{17}$ Generally, these facilities are limited in pesantren. ${ }^{19}$ In addition, the pesantren must ensure access to disinfectants and independent isolation rooms, separate from dormitories and study rooms. As a result, it has an impact on the operational burden of the pesantren. This is an obstacle, especially for salafiah pesantren with limited funding sources. This obstacle has been met by the MORA by providing financial support through Pesantren Operational Assistance (BOP) for a total of 21,173 pesantren. ${ }^{20}$ This assistance allows the provision of facilities and equipment for handling COVID-19.

\section{Weaknesses and strengths of the study}

This was a case study in a salafiah Islamic boarding school, so it only describes the situation and conditions of handling COVID-19 in pesantren with the same characteristics. Despite its limitations, this study can provide information about the stages of empowering pesantren in controlling COVID-19 and the obstacles faced by local governments and related stakeholders (Sub-district Public Health Center, COVID-19 Task Force, related institutions). Furthermore, this stage of empowerment can hopefully be replicated in other traditional Islamic boarding schools since their number represents $53.1 \%$ of all Islamic boarding schools in Indonesia. ${ }^{21}$

\section{Conclusion}

Controlling the transmission of COVID-19 through the implementation of health protocols in pesantren is not an easy matter, but it must be implemented. It requires awareness and enthusiasm from all internal pesantren ("Kiai," "Ustaz/Ustazah," "santri") and external (public health center, local Task Force of COVID-19, and local government) parties to collaborate on breaking the chain of transmission of COVID-19. Empowerment of pesantren is expected to be one of the means to pre-vent the formation of a COVID-19 cluster. 
The present findings can be used as a lesson to prevent and control COVID-19 in pesantren of other regions to prepare presential courses.

This study recommends the empowerment of the pesantren residents (teachers and students) related to health literacy, especially the implementation of health protocols, which must be improved. It is necessary to make people aware that COVID-19 is everyone's responsibility. In addition, the government should pay serious attention to Islamic boarding schools where interaction among students is a $24 / 7$ issue and promote the prevention of pesantren from becoming clusters of COVID-19 spread. This way, the continuity of pesantren as educa-tional institutions that form the character and instill val-ues in students will not stop due to the COVID-19 pan-demic.

\section{Abbreviations \\ Poskestren: Pos Kesehatan Pesantren (Pesantren Health Center); BOP: Bantuan Operasional Pesantren (Pesantren Operational Assistance); IEC: Information Education Communication; 3T: Testing, Tracing, and Treatment; URPM: UI Research and Community Service Unit}

\section{Ethics Approval and Consent to Participate}

The authors' informed consent was obtained from all subjects involved in the study.

\section{Competing Interest}

The authors declare no conflict of interest.

\section{Availability of Data and Materials}

The authors clarify sources of data or information used as study materials.

\section{Authors' Contribution}

MH designed the study and wrote the manuscript. B gave the expert opinion in the design study and critically analyzed the data and input in the manuscript drafting. J examined and drafted the manuscript.

\section{Acknowledgment}

The authors would like to thank the leader and caregiver of the AlMarjan pesantren, who had allowed the author to carry out community service in the pesantren. The authors would like to express their sincere gratitude to the UI Research and Community Service Unit (URPM-UI), providing financial support for this community service activity.

\section{References}

1. Pranata S, Nur FA, Wulandari H, Zainuddin MJ, Hidayat M. New Normal at Islamic boarding school during the COVID-19 pandemic in Sumbawa Island. In: International Conference on Social Science, Humanity, and Public Health (ICOSHIP 2020). 2021 p. 201-4.

2. Habibi A, Mukminin A, Yaqin LN, Parhanuddin L, Razak RA, Nazry NNM, et al. Mapping instructional barriers during COVID-19 outbreak: islamic education context. Religions. 2021;12(1):1-14.
3. Falikul Isbah M. Pesantren in the changing Indonesian context: history and current developments. Qudus Int J Islam Stud. 2020;8(1):65-106.

4. Pangkalan Data Pondok Pesantren Kementerian Agama Republik Indonesia. Statistik pesantren. PDPP; 2021.

5. Aditya NR. LaporCovid-19: tercatat 8.291 kasus positif COVID-19 di pesantren. Kompas.com; 2021.

6. Republik Indonesia. Keputusan Presiden (Keppres) nomor 11 tahun 2020 tentang penetapan kedaruratan kesehatan masyarakat COVID19. Pemerintah Indonesia. 2020 p. 1-2.

7. Kementerian Agama Republik Indonesia. Survei pesantren dan ancaman COVID-19: respon dan kesiapan masa new normal; 2019.

8. Kahfi S, Kasanova R. Manajemen pondok pesantren di masa pandemi COVID-19. Pendek J Pendidik Berkarakter. 2020;3(1):26-30.

9. Kementerian Kesehatan Republik Indonesia. Keputusan Menteri Kesehatan Republik Indonesia nomor hk.01.07/menkes/2322/2020 tentang panduan pemberdayaan masyarakat pesantren dalam pencegahan dan pengendalian Coronavirus Disease 2019 (COVID-19) di pesantren; 2020.

10. Pemerintah Kabupaten Lebak. Angka kejadian COVID-19 di Lebak; 2021 [cited 2021 Mar 11].

11. Victoria State Goverment. Advice for schools in managing the risk of coronavirus (COVID-19) transmission in school boarding premises and medium term. Victoria State Government; 2021.

12. National Educational Union. Coronavirus : boarding schools - members advice; 2021 [cited 2021 Jun 8].

13. Centers for Diseas Control and Prevention. Social distancing keep a safe distance to slow the spread; 2020 [cited 2021 Jun 8].

14. Broucke S Van den. Why health promotion matters to the COVID-19 pandemic , and vice versa. Health Promot Int. 2020;35(2):1-6.

15. Majelis Ulama Indonesia. Fatwa Majelis Ulama Indonesia nomor : 02 tahun 2021 tentang produk vaksin COVID-19 dari Sinovac Life Sciences Co. Ltd. China dan PT. Bio Farma (Persero). Indonesia. 2021 p. $1-8$.

16. Supriatna E. Wabah Corona Virus disease (COVID-19) dalam pandangan Islam. SALAM J Sos dan Budaya Syar-i. 2020;7(6).

17. Hosaini, Alimin M. Pembelajaran dalam era "new normal" di pondok pesantren Nurul Qarnain Jember tahun 2020. LISAN AL-HAL J Pengemb Pemikir dan Kebud. 2020;14(2):361-80.

18. Lapor COVID-19. Ancaman klaster COVID-19 di pesantren; 2021 [cited 2021 Mar 12].

19. Zahra F. Strengthening roles of pesantren in the solving problems management of Coronavirus 19. Santri J Pesantren Fiqh Sos. 2020;1(2):141-56.

20. Kontri. Verifikasi selesai, SK bantuan pesantren di masa COVID-19 segera terbit. Kemenag RI; 2020 [cited 2021 Mar 12].

21. Kementerian Agama Republik Indonesia. Analisis dan interpretasi data pada pondok pesantren, Madrasah Diniyah (Madin), Taman Pendidikan Qur'an(TPQ) tahun pelajaran 2011-2012; 2012. 